TITLE:

DYNOIDELLA CONCHICOLA, GEN.

ET SP. NOV. (ISOPODA,

SPHAEROMATIDAE), FROM JAPAN, WITH A NOTE ON ITS ASSOCIATION WITH INTERTIDAL SNAILS

AUTHOR(S):

Nishimura, Saburo

CITATION:

Nishimura, Saburo. DYNOIDELLA CONCHICOLA, GEN. ET SP. NOV. (ISOPODA,

SPHAEROMATIDAE), FROM JAPAN, WITH A NOTE ON ITS ASSOCIATION WITH INTERTIDAL

SNAILS. PUBLICATIONS OF THE SETO MARINE BIOLOGICAL LABORATORY 1976, 23(3-5):

275-282

ISSUE DATE:

1976-10-30

URL:

http://hdl.handle.net/2433/175936

RIGHT: 


\title{
DYNOIDELLA CONCHICOLA, GEN. ET SP. NOV. (ISOPODA, SPHAEROMATIDAE), FROM JAPAN, WITH A NOTE ON ITS ASSOCIATION WITH INTERTIDAL SNAILS ${ }^{1)}$
}

\author{
SABURo NISHIMURA \\ Seto Marine Biological Laboratory, Sirahama
}

With Text-figures $1-19$

While instances of parasitism are well known in the isopod crustaceans, especially among the epicarideans and cirolanids, relatively little information has hitherto been documented on their commensal relationships with other invertebrate animals (cf. Patton 1967), though such relationships are actually noticed by no means rarely in nature. One of such commensal relationships rather commonly observed is that between sphaeromatid isopods and certain groups of mollusks, and recently Glynn (1968) made an intensive study on the association of a sphaeromatid Dynamenella perforata (Moore, 1901) with the chitons Acanthopleura granulata and Chiton tuberculata in Puerto Rico.

For some years, the writer has been aware of the occurrence of a sphaeromatid species which is found frequently in association with certain intertidal snails in the vicinity of the Seto Marine Biological Laboratory. The crustacean lives beneath the snails attached to the rock surface, being hidden along the pallial grooves or around the foot of the host animals. Examining a lot of specimens available to him, the writer has been led to a conclusion that the crustacean in question represents a new species and further necessitates the establishment of a new genus. The present paper is thus prepared to give descriptions of this new isopod together with a brief note on some ecological aspects of its association with snails.

The writer's sincere gratitude is due to Mr. C. Araga of the Seto Marine Biological Laboratory who kindly furnished him with a significant part of the material.

\section{Dynoidella, gen. nov.}

DiAGNOSIs: Hemibranchiate Sphaeromatidae: Maxillipedal palp with 2nd, 3rd, 4th segments inwardly produced. Anterior pereopods without natatory setae. Exopod of 3rd pleopod 2-segmented. Exopods of 4th and 5th pleopods thin, without folds, completely or incompletely 2-segmented. Penes long and fused in basal part.

1) Contributions from the Seto Marine Biological Laboratory, No. 627.

Publ. Seto Mar. Biol. Lab., XXIII (3/5), 275-282, 1976.

(Article 20) 
Seventh pereonite and pleotelson without any armouring processes in both sexes. Pleotelson with an apex notched similarly in both sexes. Uropods lamellate.

Type Species: Dynoidella conchicola, sp. nov.

The new genus most closely resembles Dynoides Barnard, 1914, which is characterized, however, by its unsegmented exopod of 3rd pleopod and by the presence of a prominent median process on pleotelson in $\delta$. The present new genus also resembles Sphaeramene Barnard, 1914, and Parisocladus Barnard, 1914, on the other hand; these two genera are, however, easily distinguished from the new genus by the structure of penes which are not fused but either entirely separated from each other or contiguous only at base.

\section{Dynoidella conchicola, sp. nov.}

\section{(Japanese name: Kaiyadori-umisemi, nov.)}

Figs. 1-19.

Material Examined: 1) 20 specimens. Sakata, Sirahama, Wakayama-Ken, Japan; rocky shore, middle intertidal zone; associated with the snail Theliostyla albicilla (Linné). Coll. S. Nishimura; Nov. 2, 1968. 2) 5 specimens, including 1 holotype 0 . Ezura, Sirahama; rocky shore, lower intertidal zone; associated with Theliostyla albicilla. Goll. S. Nishimura; Nov. 3, 1968. 3) 17 specimens. Sakata, Sirahama; rocky shore, middle intertidal zone; associated with Theliostyla albicilla. Coll. S. Nishimura; Nov. 3, 1968. 4) 31 specimens. North coast of the campus of the Seto Marine Biological Laboratory, Sirahama; rocky shore; associated with the limpets Cellana nigrolineata (Reeve) and C. grata stearnsi (Pilsbry). Coll. C. Araga; Dec. 18, 1968.

The above material contained many juvenile specimens in addition to adult males, but no adult female was found. Specimens including holotype are deposited at the museum of the Seto Marine Biological Laboratory (SMBL-Type 271).

Description: Male-Body (Fig. I) nearly parellel-sided, moderately convex, surface not granulated but finely setulose all over. Seventh pereonite bordered laterally by the epimerae of 6 th pereonite. Pleon segments 2-4 fused, the suture between segments 2 and 3 represented only by a faint notch, and the same between segments 3 and 4 by an incision extending medially half way. Pleotelson nearly triangular in outline, convex in center but rather flat near margins and towards the apex, smooth and without any tubercles or other structural rugosities on the surface; along lower inner margins it is thickened and somewhat shelved; apex produced with a rounded slit without teeth at the tip.

Cephalon rather large, with a rostral process and slightly sinuously rounded frontal margins. Eyes large; with ca. 70 ocelli.

First antenna (Fig. 2) short, reaching the middle of lst pereonite; flagellum with 9 segments, nearly as long as 2 nd to 4 th peduncular segments together. Second 
antenna (Fig. 3) slender, reaching the middle of 2 nd pereonite, flagellum with 15 segments, $3 / 2$ times as long as distal 3 peduncular segments together.

Epistome (Fig. 4) truncate-triangular, embracing the basal part of upper lip which is as long as wide and with rounded distal margin. Lower lip (Fig. 5), lobes oval, apically rounded.

Right mandible (Fig. 6), incisor with 3 teeth and 5-dentate lacinia mobilis, to

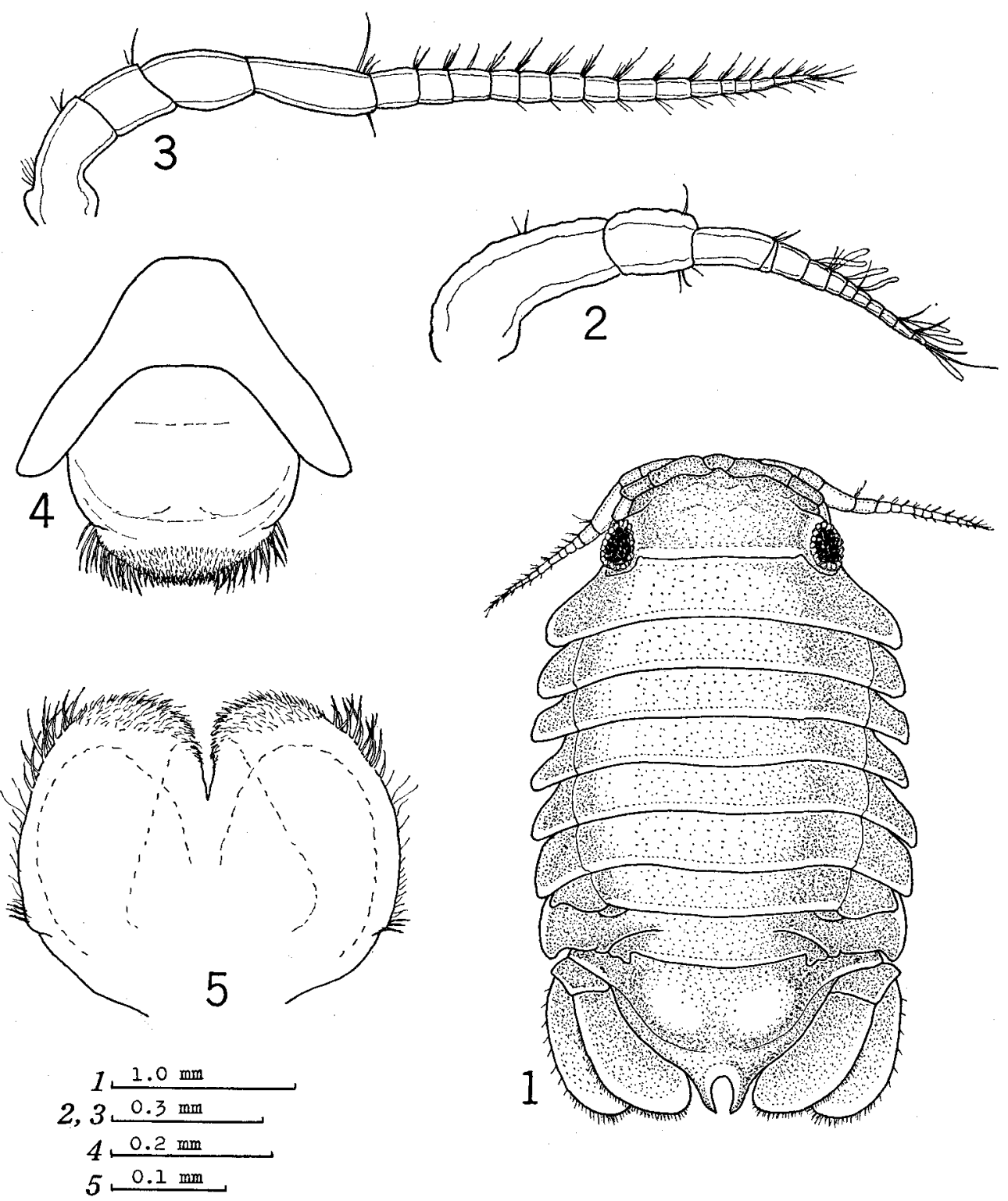

Figs. 1-5. Dynoidella conchicola, gen. et sp. nov., male.

1. Holotype, from Ezura, Sirahama. 2. First antenna. 3. Second antenna. 4. Epistome and upper lip. 5. Lower lip. 
which are attached 3 pectinate setules. Left mandible (Fig. 7), incisor with 4 teeth and lacinia mobilis which is armed with 3 dentations and 1 or 2 pectinate setules. Mandibular palp (Fig. 6) 3-segmented, 1st segment nearly twice as long as 2nd segment which is subequal to 3rd segment; distal 2 segments bear each setules on the outer margin, 2 on the 2 nd and ca. 11 on the 3 rd.

First maxilla (Fig. 8), inner lobe with 1 simple minute setule and 4 pectinate setules, outer lobe with 3 teeth and 2 dentate spines.

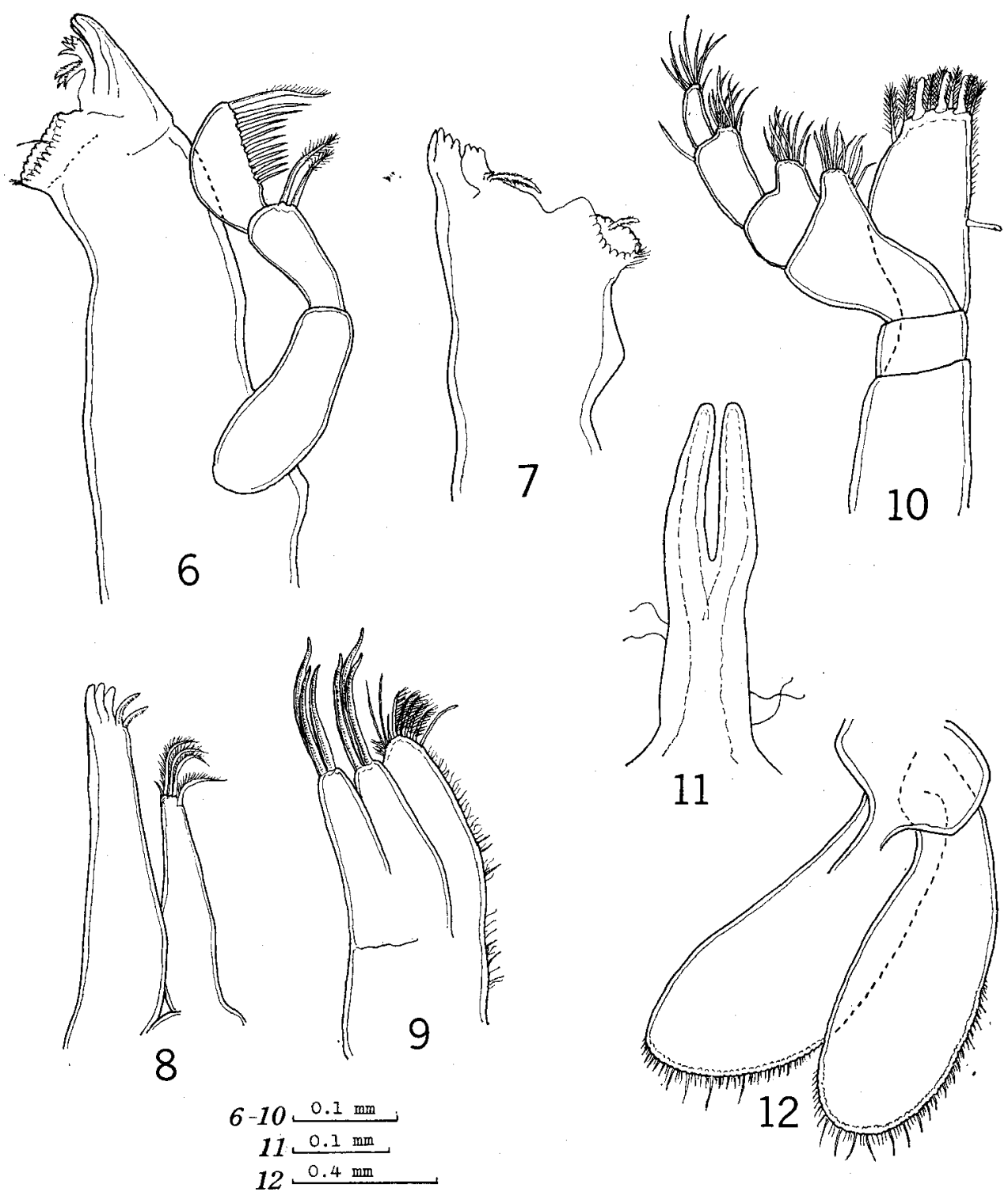

Figs. 6-12. Dynoidella conchicola, gen. et sp. nov., male.

6. Right mandible, with mandibular palp. 7. Left mandible, distal part. 8. First maxilla.

9. Second maxilla. 10. Maxilliped. 11. Penes. 12. Uropod, ventral view. 
Second maxilla (Fig. 9), inner lobe with 3-4 simple setules and ca. 5 pectinate setules between, both lappets of outer lobe each with 3 dentate spines.

Maxilliped (Fig. 10), palp 5-segmented, 2nd and 3rd segments provided each with a prominent lobe, while 4th segment with a weak lobation. Endite extending slightly beyond the distal end of 3rd segment of palp.

First pereopod short, robust, carpus much shortened, overlapped by strongly produced merus. Second pereopod most slender (but not the longest) of all pereopods, propodus and carpus particularly lengthened, merus moderately produced. Third to 7 th pereopods nearly of the same structure; 3rd pereopod moderately robust, propodus and merus more strongly produced than in $2 \mathrm{nd}$; 4th to 7 th percopods progressively longer and slenderer, 7th approaching to the shape of 2nd and the longest of all pereopods.

Penes (Fig. 11) long, rami fused in the proximal half.

First pleopod (Fig. 13), exopod with ca. 20 setae on the distal to outer margin and 1 strong, hooked spine at the proximal outer corner, endopod with ca. 14 setae on the distal to outer margin. Second pleopod (Fig. 14), exopod with ca. 25 setae on the distal to outer margin, endopod with ca. 16 setae on the distal to outer margin, inner distal corner of protopod with 2 hooked spines. Male stylus (Fig. 15), 3/2 times as long as endopod and extending beyond the apex of endopod by $1 / 3$ of its own length, distally tapers to a dull tip. Third pleopod (Fig. 16), exopod 2-segmented, with ca. 19 setae on the outer margin of proximal segment and ca. 17 setae on the distal to outer margin of distal segment, endopod with ca. 15 setae on the distal margin. Fourth pleopod (Fig. 17), exopod 2-segmented, thin, endopod thick with deep transverse folds; no setae at all. Fifth pleopod (Fig. 18), exopod incompletely 2-segmented, thin and with 2 subapical squamiferous protuberances, endopod thick with deep transverse folds; no setae at all.

Uropod (Figs. 1 and 12), rami lamellate, lanceolate, and extending as far as or slightly beyond the pleotelsonic apex; both rami subsimilar in size and shape, or outer ramus a little smaller and slightly more rounded at the tip than inner ramus.

Female-Since no fully matured female specimen was available in the material, the description is suspended herein.

Measurements: Holotype 0 -Body length $3.6 \mathrm{~mm}$, body width $2.1 \mathrm{~mm}$ (on 5th pereonite), cephalon width $1.3 \mathrm{~mm}$, pleotelson width $1.8 \mathrm{~mm}$. In December, 1968, adult males as large as $4.2 \mathrm{~mm}$ in body length were collected (Material 4; see p. 276).

ColOr IN LIFE: Mostly variegated; scattered with yellowish-brown, blackishbrown or reddish-brown blotches all over. Eyes and uropodal rami greyish-brown. Guanine patches reflecting light blue phosphorescence scattered on the dorsal surface, especially those arranged in pairs on the submedian part on 4th pereonite and on pleotelson are prominent.

Ecologtcal Notes: So far the present species has been collected exclusively 
from under certain snails attached to the rock surface exposed at ebb tide. The snails found harbouring the isopod are Theliostyla albicilla (Neritidae), Cellana nigrolineata and C. grata stearnsi (Patellidae). At Sakata, near the type locality Ezura, of Sirahama, the majority of individuals of Theliostyla albicilla, representing one of the
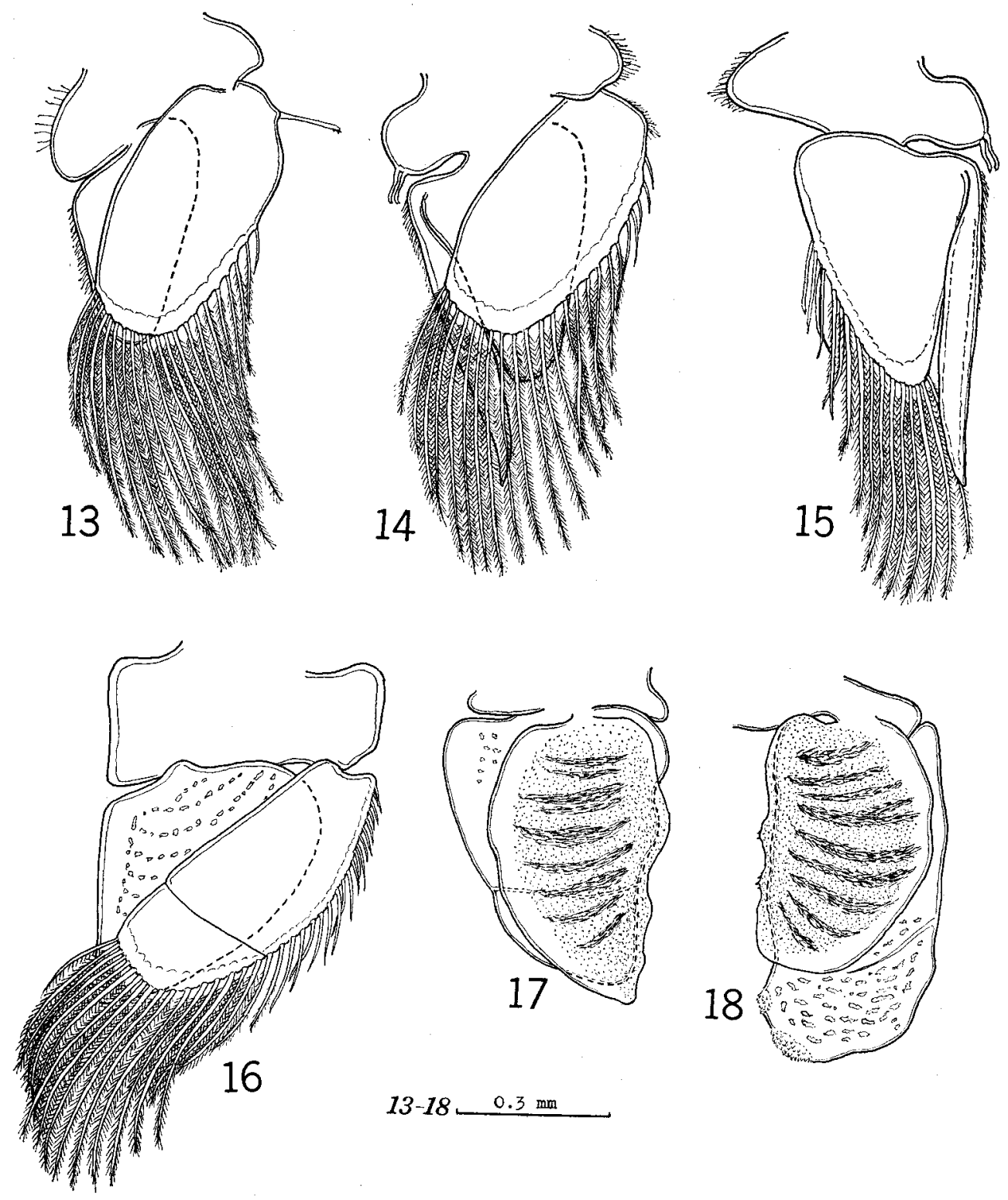

$13-18 \simeq \quad 0.3 \mathrm{~mm}$

Figs. 13-18. Dynoidella conchicola, gen. et sp. nov., male.

13. First pleopod. 14. Second pleopod. 15. Endopod of 2nd pleopod. 16. Third pleopod. 17. Fourth pleopod. 18. Fifth pleopod. 
most abundant intertidal snails there, were observed each to harbour 1 to 5 , mostly 2 or 3 isopods, while no isopods could be discovered under Monodonta labio (Trochidae), another snail equally abundant at that locality (obs. Nov. 3, 1968). The isopods were found attached to the surface of pallial groove, along mantle edge, or on the dorsal surface of foot of the host snail (Fig. 19), and no walking movement was observed on the crustaceans though the snail moved around vigorously in a water-filled vessel. It is interesting that the isopod seems apparently to select as hosts the limpets or limpet-like snails such as patellids and neritids rather than typical gastropods, and it is estimated that where these limpets or limpet-like snails are common, the present isopod may be equally abundant. Very frequently, a kind of the stalked protist (? suctorian) was observed attached to the proximal outer margins of every pereopod and similarly to the basal outer margin of penes, a few to several individuals in cluster at each position.

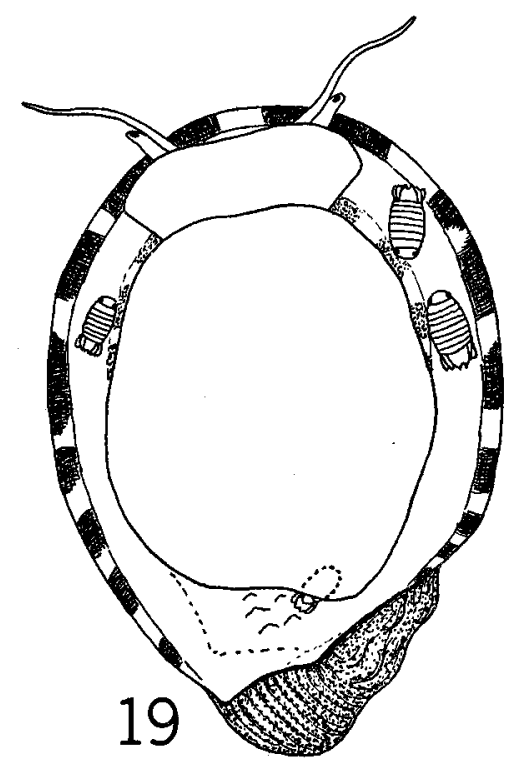

Fig. 19. Ventral view of a specimen of Theliostyla albicilla, showing the association of Dynoidella conchicola with the snail. Note three isopods attached around the mantle edge of the host, while another on the posterior dorsal surface of the foot, partially concealed.

Remarks: The most prominent feature of this species is the shape of penes which, instead of being separated throughout their length, are fused in the basal half. In this character, the present species is unique among hemibranchiate sphaeromatids and shares only with the species of the genus Dynoides (D. serratisinus Barnard, $D$. barnardi Baker and $D$. dentisinus Shen). The new species is separated, however, from the Dynoides species by the structure of 3rd pleopod, the exopod of which is 2-segmented instead of being unsegmented. Moreover, the present new species lacks the median process on pleon, a characteristic structure in males of the Dynoides species. A new genus thus seems to be necessary to accomodate the present species. 


\section{REFERENCES}

Baker, W.H. 1928. Australian species of the isopod family Sphaeromidae (continued). Transact. Proc. Rep. Roy. Soc. S. Australia, vol. 52, pp. 49-61.

Barnard, K.H. 1914. Contributions to the crustacean fauna of South Africa 3. Additions to the marine Isopoda, with notes on some previously incompletely known species. Ann. S. African Mus., vol. 10, pp. 325a-358a, 359-442.

Glynn, P.W. 1968. Ecological studies on the associations of chitons in Puerto Rico, with special reference to sphaeromid isopods. Bull. Mar. Sci., vol. 18, pp. 572-626.

Patton, W.K. 1967. Commensal Crustacea. Proc. Symp. Crustacea, Ernakulam, India, Jan. 1215, 1965, pt. III, pp. 1228-1243.

Shen, C.J. 1929. Description of a new isopod, Dynoides dentisinus, from the coast of North China. Bull. Fan Mem. Inst. Biol., vol. 1, pp. 63-78. 